\title{
選択成長法による分子性結晶ナノ構造の形成
}

\author{
上野啓司・島田敏宏・小間 篤 \\ 東京大学大学院理学系研究科 - 113 東京都文京区本郷 7-3-1
}

(1997 年 1 月 31 日受理)

\section{Fabrication of Molecular Crystal Nanostructures by a Selective Growth Method}

\author{
Keiji UENo, Toshihiro SHIMADA and Atsushi Koma \\ Department of Chemistry, The University of Tokyo \\ 7-3-1 Hongo, Bunkyo-ku, Tokyo 113
}

(Received January 31, 1997)

\begin{abstract}
Over the years, organic molecular crystals including metal-phthalocyanines or $\mathrm{C}_{60}$ have attracted much attention as source materials for the next generation high-density optoelectronic devices. To fabricate such devices, formation of desired nanostructures is required. But it is difficult to apply conventional photolithography techniques to create the nanostructures of such organic materials. As the method to fabricate a nanostructure of an organic material, we payed much attention to a selective growth technique, which utilizes differences in the sticking coefficients of an organic material on various substrates. Here, we report the results of the selective growth of organic molecules on alkali halides and layered materials as the substrates. We also discuss a novel method to fabricate the organic molecule nanostructure, which takes advantage of a combination of the selective growth and scanning probe microscope lithography techniques.
\end{abstract}

\section{1. は じめに}

超薄膜成長技術や超微細加工技術の発展により，ナノ メータースケールで構造が制御された量子細線や量子ド ットといった量子ナノ構造の作製が現実のものとなっ た。量子ナノ構造の研究は特にガリウム砒素やシリコン 等の無機半導体の分野において盛んであり, 量子細線/ 量子ドットレーザー，単電子トランジスタ等の量子ナノ デバイスの研究が精力的に行われている1,2)。また，走 查型トンネル顕微鏡（STM）や原子間力顕微鏡（AFM） 等の走查型プローブ影微鏡（SPM）を用いて固体表面を 加工し，原子スケールのデバイスを作製しようとする研 究も始められている。

一方，有機分子性結晶を次世代の機能性材料として用 いる研究も活発に行われており，マクロな集合体として の有機分子性結晶の持つ光学非線形性や光電変換機能な どに着目したデバイスはすでに実用化されている。また 有機分子を光の波長以下で構造を制御して配列し，回折 効果と分子の光学的特性を組み合わせて機能の発現を狙
う “photonic crystal” ”)や，さらに有機分子 1 個 1 個が持 つ機能性を利用しようという極小デバイスの研究も始め られている。有機分子は，それが持つ官能基 1 つの違い で異なる特性を示す。このため 1 つの分子を 1 機能単位 として利用できれば，現在の無機半導体デバイスを遥か に凌駕する超高密度デバイス，いわゆる「分子素子」の 実現も期待できる4, 5)。

しかし，現状での有機分子性結晶のデバイスへの応用 は，マクロな大きさの単結晶や薄膜を用いたものがほと んどである。「分子素子」につながるようなナノ構造の 形成はおろか, 普通の無機半導体では可能なナノサイズ の微細パターンを有機薄膜上に形成する，といったこと む殆ど実現していない。その理由として，有機分子間の 結合がファンデアワールスカのような弱い結合であるた め, 単結晶や薄膜が非常に脆くなる, ということがあげ られる。また，光リソグラフィーで用いられるレジスト 材料も専ら有機物質であり，加工したい有機薄膜との間 に明確な差異が生じないという問題がある。このため従 来の技術を適用した場合に，有機薄膜はマスク形成時や 
その剥離プロセスの段階でダメージを受け易く, 微細加 工が困難となっている。

この問題を解決するために, 我々は「選択成長法」に より有機分子性結晶のナノ構造を形成することを考案し た。これまで我々の研究室では, 数多くの有機分子性結 晶の, 超高真空中での薄膜成長を様々な基板上に試み, その結晶性, 配向性, 成長機構等を調べてきた ${ }^{6 \sim 9) 。 そ ~}$ の過程で, 有機分子の基板への付着確率が基板温度だけ でなく基板の種類によって異なり, 付着成長できる基板 温度の上限值も基板物質間で大きく異なることを発見し た。そこで, この成長可能温度の上限が大きく異なる(そ の温度を $T_{\mathrm{A}}, T_{\mathrm{B}}, T_{\mathrm{A}}<T_{\mathrm{B}}$ とする） 2 種類の物質 $\mathrm{A}, \mathrm{B}$ を 選び, 一方の薄膜を他方の基板上の一部だけにへテロ成 長することを考える。この基板上に先の有機分子を，基 板温度 $T_{\mathrm{S}}$ が $T_{\mathrm{A}}<T_{\mathrm{S}}<T_{\mathrm{B}}$ となる範囲で成長すれば, 成長 可能温度の上限が高い物質 $\mathrm{B}$ の上にだけ, 選択的にそ の有機分子を成長することが可能になる。

後述するように, 基板となる物質は無機物質であり, 微細な選択成長領域の形成手法として通常の光リソグラ フィー技術を用いることができる。また，一方の薄膜の ヘテロ成長後に, SPM を用いて薄膜の超微細剥離加工 を行い, 原子スケールでの選択成長領域を形成すること も期待できる。この微細加工後に有機分子を選択成長す れば, 形成したパターン通りの有機分子による微細構造 を作製することができる，というのが我々のアイデアで ある。

本稿では, 実際にこの有機分子性結晶の選択成長を実 現した 2 種類の物質系について報告する。まず, アルカ リハライド間でのへテロ成長により作製した基板上へ の, バナジルフタロシアニン (VOPc) 分子の選択成長 ${ }^{10)}$ について述べる。次に, 層状物質間でのへテロ成長によ り作製した基板上への $\mathrm{C}_{60}$ 分子の選択成長 ${ }^{11}$ について述 ベる。最後に, AFMを用いて微細加工を施した層状物

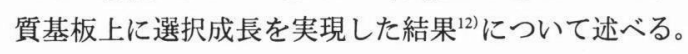

\section{2. アルカリハライド/VOPc 系での選択成長}

$\mathrm{NaCl}$ や $\mathrm{KBr}$ などのアルカリハライドは, バンドギャ ップが広く可視光領域で透明であるため, 有機分子薄膜 の光学的特性を調べる際の基板として広く用いられてき た。またその単結晶基板上では, 一部の有機分子が結晶 軸方向を揃えてエピタキシャル成長をすることが知られ ており6,8,9), 前章で述べたような光デバイス作製の基 板に適している。我々はアルカリハライド単結晶基板上 に, 超高真空下で種々の金属フタロシアニンの薄膜成長 を行ってきたが, その一つである VOPc の付着確率の温 度依存性が, 基板の種類によって大きく異なることを発

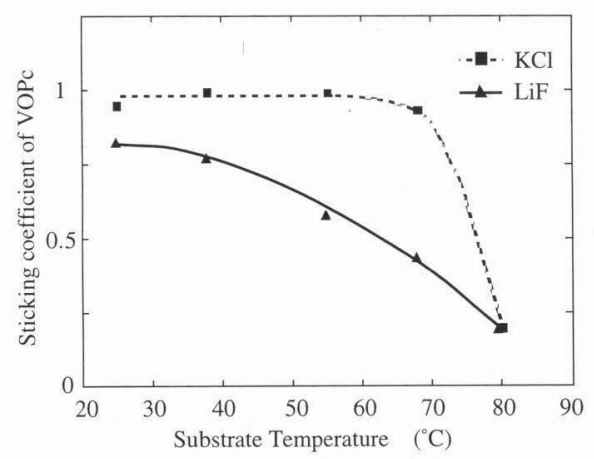

Fig. 1 The sticking coefficient of VOPc grown on $\mathrm{KCl}$ and $\mathrm{LiF}$ substrates as a function of substrate temperatures. The values are normalized so as to make that for the film grown on $\mathrm{KCl}$ at room temperature equal.

見した。この性質を利用して選択成長を試みた結果を以 下に示す。

Fig. 1 は, VOPc の付着確率の温度依存性を, LiF およ び $\mathrm{KCl}$ の単結晶基板に対して調べた結果である。入射 する VOPc 分子線量は, 基板横の水晶振動子膜厚計で測 定して 25 分子層相当となるように制御し, 基板への付 着量は, $\operatorname{VOPc} の \mathrm{Q}$ バンド領域 $(550 \sim 1000 \mathrm{~nm})$ の光吸 収を積分した值から求めている。基板温度が室温の時点 で既に, VOPc $の \mathrm{LiF}$ 基板に対する付着確率は $\mathrm{KCl}$ 基板 に対してよりも低い。7 $0^{\circ} \mathrm{C}$ までは $\mathrm{KCl}$ に対する付着確 率がほぼ 1 なのに対し, $\mathrm{LiF}$ に対しては単調減少し, $70^{\circ} \mathrm{C}$ では 0.5 を切っている。この測定結果から, $\mathrm{LiF}$ と $\mathrm{KCl}$ が表面に混在する基板上に, 基板温度 $55^{\circ} \mathrm{C}$ から $70^{\circ} \mathrm{C}$ の範囲で VOPc を照射すれば， $\mathrm{KCl}$ 上に選択成長するこ とが期待される。

選択成長を行うためのアルカリハライド基板は, LiF 単結晶基板上に $\mathrm{KCl}$ 薄膜を分子線エピタキシー（MBE） 法によりへテロ成長して作製した。LiF と KCl は格子定 数が $0.402 \mathrm{~nm}$ および $0.629 \mathrm{~nm}$ と大きく異なる。しかし イオン結合性のヘテロ界面では格子不整合が緩和され, 結晶性の良い平坦なへテロエピタキシャル薄膜が成長可 能であることが，斉木らにより報告されている ${ }^{13,14) 。 こ ~}$ のように単結晶性を維持したへテロ基板を作製すること は, その上に選択成長する有機分子薄膜の配向性を向上 し，光デバイスへの応用を図る上で重要である。

選択成長の手順は, まず単結晶 $\mathrm{LiF}$ を䢃開し, その上 にパターン形成のための銅板によるマスクをかぶせた 後, MBE 装置内に導入する。表面を加熱清浄化した後, 厚さ約 $60 \mathrm{~nm}$ の $\mathrm{KCl}$ 薄膜を成長する。この試料を大気 中に取り出し, マスクを取り外した後再び超高真空内に 戻し, 表面を加熱清浄化した後に基板温度 $55^{\circ} \mathrm{C}$ で 25 
分子層相当の VOPc を照射した。

Fig. 2 に, VOPc 照射後に大気中に取り出した試料の 写真を示す。 $\mathrm{KCl}$ 薄膜は基板右半分の, コントラストが 異なる半月状の部分にだけ成長してある。VOPc 成長前 には左右でコントラストの差は見られておらず, VOPc 薄膜が $\mathrm{KCl}$ 上に選択成長していることが確認できる。

一般にある分子が平坦な基板上に結晶成長する場合, その結晶成長核の生成頻度は, 基板表面でのその分子の 過飽和度に依存し, ある臨界過飽和度を超えると結晶成 長が開始する ${ }^{15)}$ 。この臨界過飽和度が基板物質および基 板温度に依存するため, 選択成長が可能になると考えら れる。Fig. 3 は $\mathrm{KCl}$ および $\mathrm{LiF}$ の単結晶䢃開面に, 基板
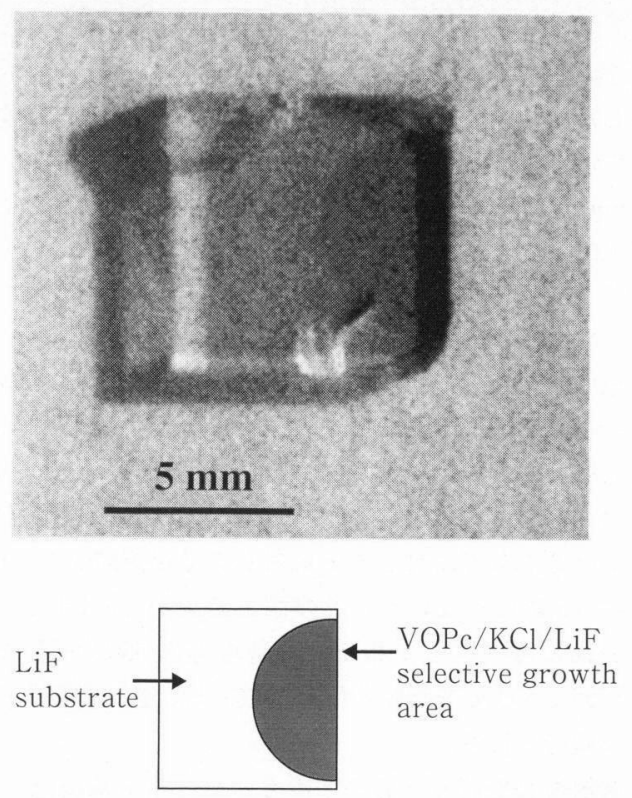

Fig. 2 A photograph of an example of the patterning by selective epitaxy. Beneath the colored VOPc portion lies a $\mathrm{KCl}$ epitaxial pattern fabricated by the MBE of $\mathrm{KCl}$ through a mask.
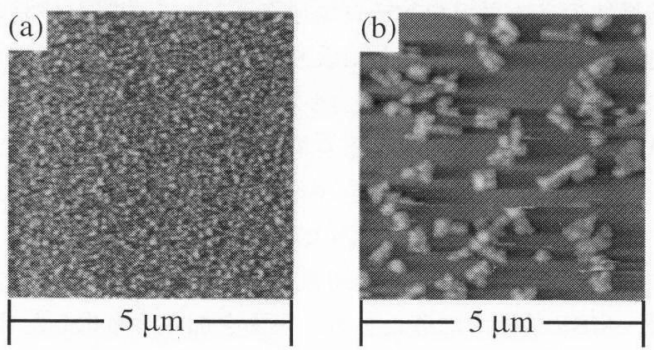

Fig. 3 AFM images of VOPc films grown on (a) $\mathrm{KCl}$ and (b) $\mathrm{LiF}$ at room temperature. The irradiated amount of VOPc was 15-monolayer equivalent.
温度室温で VOPc を 15 分子層相当成長した試料の AFM 像である。この像の通り成長核密度が全く異なり，2つ の物質間での臨界過飽和度が大きく異なっていることが 窥える。

今回の実験では単純なマスクを用いたため, 形成した $\mathrm{KCl}$ の選択成長領域はかなり広いものであったが，我々 は非水性レジスト材料および有機溶媒によるレジスト剥 離を行うことで, $\mu \mathrm{m}$ スケールでアルカリハライド薄膜 のパターニングを行い選択成長領域を形成することに成 功している。また他の幾つかの有機物質でも, 付着確率 の基板物質依存性が観察されており，アルカリハライド 上での選択成長法が種々多様な有機物質で適用可能なこ とが予想されている。

\section{3. 層状物質 $/ \mathrm{C}_{60}$ 系での選択成長}

グラファイト，雲母および $\mathrm{MoS}_{2}$ や $\mathrm{TaS}_{2}$ 等の遷移金 属ダイカルコゲナイドに代表される層状物質は, 単位層 内は共有結合やイオン結合などの強い結合で構成されて いるが，層間は主に弱いファンデアワールスカで結合し ている。そのため容易に薄片状に䢃開し, その辟開面に は活性なダングリングボンドが現れない。このような表 面上に有機分子性結晶を成長する場合, 基板から受ける 束縛力が小さいため, バルク結晶と同じ結晶構造を保っ て単結晶成長することが期待できる。我々はこの観点か らこれまで多くの有機分子の薄膜成長を層状物質基板上 に試みてきたが7, 9)，ここでも付着確率の基板物質依存 性が観察され，さらに選択成長を行うことに成功した。 本章では有機分子性結晶として $\mathrm{C}_{60}$, 基板として層状物 質の $\mathrm{MoS}_{2}$ と $\mathrm{GaSe}$ を用いて選択成長を行った結果につ いて述べる。

選択成長に用いた基板は, 超高真空中で GaSe 単層膜 を $\mathrm{MoS}_{2}$ 基板上に $\mathrm{MBE}$ 法によりへテロエピタキシャル 成長して作製した。 $\mathrm{MoS}_{2}{ }^{16)}$ および $\mathrm{GaSe}^{17)}$ は共に 2 次元 的な結晶構造を持つ層状物質であるが，その単位層の構 造および格子定数は大きく異なる。しかし両者はへテロ 界面で弱いファンデアワールスカを介して接合するた め, GaSe 薄膜はそれ自身の結晶構造を持って単結晶成 長することができる。この層状物質間のへテロエピタキ シャル成長は, 小間によりファンデアワールス・エピタ キシーと名付けられ, 多種多様な層状物質間で実証され ている18, 19)。

GaSe 薄膜の場合は, 基板温度と成長速度を制御する ことで，ほぼ完全に $\mathrm{MoS}_{2}$ 基板表面を覆った単層の膜を 形成することが可能である ${ }^{20)}$ これまでの $\mathrm{C}_{60}$ 薄膜の成 長実験から， $\mathrm{C}_{60}$ 分子は $\mathrm{MoS}_{2}$ 基板上では基板温度 250 ${ }^{\circ} \mathrm{C}$ 程度までエピタキシャル成長するのに対し, GaSe 薄 


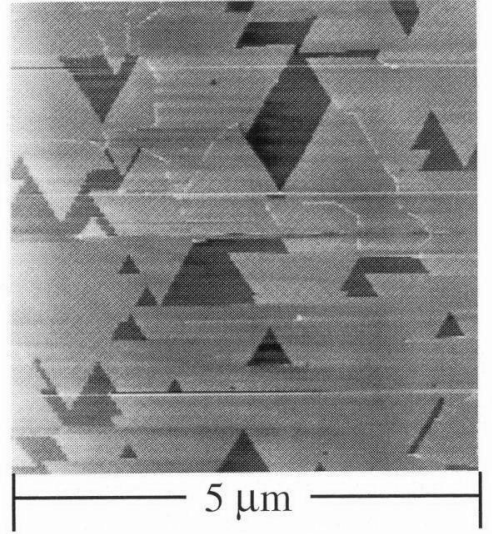

Fig. 4 An AFM image of a submonolayer film of GaSe on a $\mathrm{MoS}_{2}$ substrate. Darker regions correspond to the bare $\mathrm{MoS}_{2}$ substrate and brighter regions correspond to the GaSe film.

膜上では $180^{\circ} \mathrm{C}$ 程度で殆ど成長しなくなることが判明 した。そこで, Fig. 4 の AFM 像に示すような, 被覆率 が 1 以下の $\mathrm{GaSe}$ 単層膜を $\mathrm{MoS}_{2}$ 基板上に成長し, これ を選択成長の基板として用いることを試みた。

$\mathrm{GaSe}$ は $\mathrm{MoS}_{2}$ 基板上で正三角形のドメインを形成し, 成長するにつれ各ドメインが融合していく。しかし 1 層 完全に成長する前の表面には，そのような GaSe ドメイ ンで囲まれた， 1 辺が $20 \mathrm{~nm}$ 程度の正三角形の「穴」や, 幅が数十 $\mathrm{nm}$ で長さが数百 $\mathrm{nm}$ 近い「溝」などが多数存 在し, その中に $\mathrm{MoS}_{2}$ 表面が露出している。この上に $\mathrm{C}_{60}$ 分子を基板温度 $180^{\circ} \mathrm{C} \sim 250^{\circ} \mathrm{C}$ の範囲で成長すれば, 露 出した $\mathrm{MoS}_{2}$ 表面にだけ, ナノスケールの $\mathrm{C}_{60}$ 領域が成 長すると予想される。

Fig. 5 は, 上記の $\mathrm{GaSe} / \mathrm{MoS}_{2}$ ヘテロ構造基板に, $\mathrm{GaSe}$ の成長と同じ $\mathrm{MBE}$ 成長室内で $\mathrm{C}_{60}$ を分子線強度 $4 \times 10^{-6}$ $\mathrm{Pa}$, 基板温度 $180^{\circ} \mathrm{C}$ で照射し, その後大気中に取り出 して観察した AFM 像である。(a) は成長初期段階の AFM 像で, $\mathrm{C}_{60}$ 分子が GaSe ドメインのステップ端から成長 を開始し, $\mathrm{MoS}_{2}$ 領域内に拡がっている様子がわかる。(b) は 5 分間成長した後の AFM 像で, 明るい多角形の部分 が成長した $\mathrm{C}_{60}$ の領域, 残りの部分が $\mathrm{GaSe}$ 単層膜の領 域である。 $\mathrm{C}_{60}$ 分子は $\mathrm{GaSe}$ で覆われていない, 露出し た $\mathrm{MoS}_{2}$ 上にだけ成長し, GaSe 上には殆ど吸着してい ない。なお $\mathrm{GaSe}$ 領域上に見られる白い斑点は, AFM 観察中に $\mathrm{C}_{60}$ ドメインがカンチレバーにより削られて生 じたものである。 $C_{60}$ 照射中にこの時点で観察された反 射高速電子線回折像からは, $\mathrm{C}_{60}$ 分子は $\mathrm{MoS}_{2}$ 領域上で バルク単結晶格子と同じ格子定数の六方稠密格子を組ん で成長していること, つまり単に吸着しているだけでな
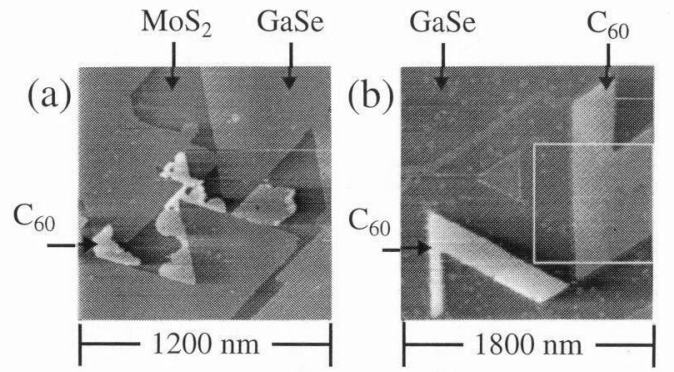

(c)

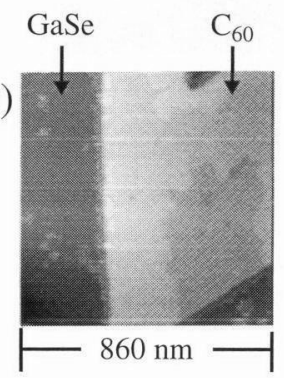

(d)



Fig. 5 AFM images of $\mathrm{C}_{60}$ nanostructures formed by selective growth on $\mathrm{MoS}_{2}$ substrates with GaSe masks. (a) After 1 min growth of $\mathrm{C}_{60}$; (b) After 5 min growth of $\mathrm{C}_{60}$; (c) An enlarged image of the rectangular area in (b); (d) One of the smallest structures of $\mathrm{C}_{60}$.

\section{く，単結晶成長していることが確認されている。}

次に（c）は（b）中の正方形の領域を拡大したもので, $\mathrm{C}_{60}$ が 3 層目まで成長していることを示す複数のステッ プが存在している。 $\mathrm{C}_{60}$ はさらに 4 5 層程度 $\mathrm{MoS}_{2}$ 上に 成長しても, GaSe上に溢れ出ないことが AFM 観察さ れており，成長の選択性が非常に高いことがわかる。(d) はこの試料で観察された最小の $\mathrm{C}_{60}$ 領域の 1 つである が, 幅が $20 \mathrm{~nm}$ 程度, つまり $\mathrm{C}_{60}$ が 20 個並ぶ程度の幅 の $\mathrm{C}_{60}$ ナノ構造が選択成長により形成可能である。

以上の実験結果からは, 基板温度 $180^{\circ} \mathrm{C}$ における $\mathrm{C}_{60}$ 分子と $\mathrm{GaSe}$ 表面間の相互作用が， $\mathrm{C}_{60}$ 分子と $\mathrm{MoS}_{2}$ 表面 間の相互作用よりもかなり弱く, さらに $\mathrm{C}_{60}$ 分子間の相 互作用よりも弱いことが示されている。Fig. 6 にこの成 長の模式図を示す。 $\mathrm{GaSe} / \mathrm{MoS}_{2}$ ヘテロ構造基板上へ入 射する $\mathrm{C}_{60}$ 分子の5ち, $\mathrm{GaSe}$ 上に到達したものは表面 滞在時間が短く, 成長核を形成することなく再蒸発する。 一方 $\mathrm{MoS}_{2}$ 上へ入射したものは表面滞在時間が長く, 表 面拡散の後 $\mathrm{GaSe}$ 単層膜のステップ端に到達し, 吸着す る。その後さらに $\mathrm{MoS}_{2}$ 上に入射してくる $\mathrm{C}_{60}$ 分子は, 表面拡散の後, 既に成長している $\mathrm{C}_{60}$ ドメインに捕らわ れていく。こうして露出した $\mathrm{MoS}_{2}$ 領域だけが $\mathrm{C}_{60}$ 分子 で埋められていく。 $\mathrm{MoS}_{2}$ 領域がこうして $\mathrm{C}_{60}$ 単分子層 で覆い尽くされた後は, その $\mathrm{C}_{60}$ 領域の上でだけ次の $\mathrm{C}_{60}$ 

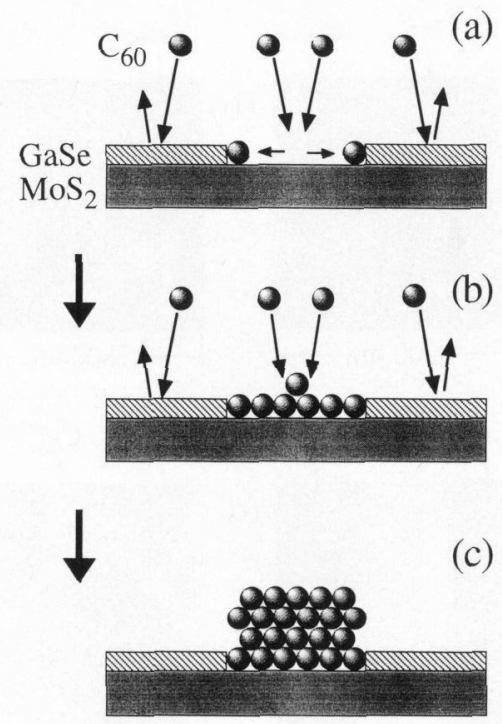

Fig. 6 A schematic view of the formation of a $C_{60}$ nanostructure on a $\mathrm{MoS}_{2}$ substrate covered with a GaSe mask.

層の成長が進み, 数層に渡る厚さの $\mathrm{C}_{60}$ ドメインが, $\mathrm{GaSe}$ 上に溢れ出ることなく形成されていく。

\section{AFM を用いた選択成長領域加工}

前章で述べた実験では, $\mathrm{C}_{60}$ 分子を選択成長している 領域は GaSe 単層膜の成長の際に被覆されなかった $\mathrm{MoS}_{2}$ 表面であり, その形状を自由に制御することは行 っていない。アルカリハライド基板上での選択成長と同 様に，パターンを切り抜いたマスクをかぶせて GaSe 薄 膜を成長したり，あるいは光リソグラフィーにより成長 した GaSe 薄膜を除去することで，任意の形状の選択成 長領域を形成することは可能である。しかし我々はその ような手法より更に微細な，極限的には原子レベルでの 加工も可能な, SPM を用いた表面加工法に着目した。

層状物質表面をSPM を用いて加工する試みは以前か ら数多く行われており, 各単位層を 1 層 1 層はぎ取って いったり ${ }^{21}$ 22)，さらには表面原子 1 個 1 個を除去して文 字を描画するようなことも行われている $\mathrm{AFM}$ を用いて $\mathrm{MoS}_{2}$ 基板上の $\mathrm{GaSe}$ 単層膜を切削してナ ノスケールの $\mathrm{MoS}_{2}$ 露出領域を形成し， $\mathrm{C}_{60}$ の選択成長 を試みた結果について述べる。

実験手順を Fig. 7 に示す。まず $\mathrm{MoS}_{2}$ 基板表面をほぼ 完全に覆う $\mathrm{GaSe}$ 単層膜を MBE 成長し, 次に試料を大 気中に取り出して AFM 加工を行う。GaSe 単層膜の切 削は, 表面形状観察に用いるのと同一の汎用 $\mathrm{Si}_{3} \mathrm{~N}_{4}$ カン チレバーを, 基板表面に押しつけて往復運動することで 行う。加工した試料は再び MBE 装置に戻し, 選択成長

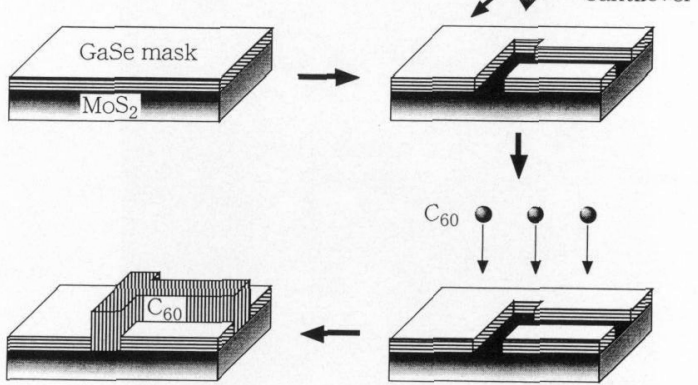

Fig. 7 A schematic view of the selective growth of $\mathrm{C}_{60}$ molecules on a nanoscale pattern formed on a $\mathrm{GaSe} / \mathrm{MoS}_{2}$ heterostructure by AFM lithography.

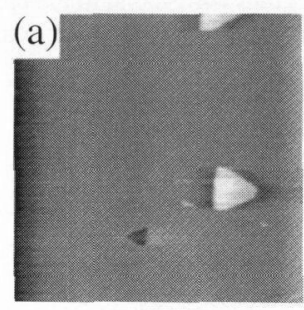

$100 \mathrm{~nm}$

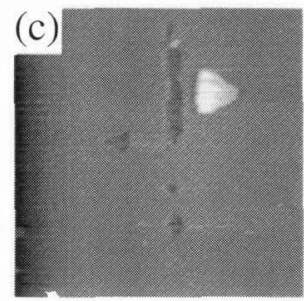

$100 \mathrm{~nm}$

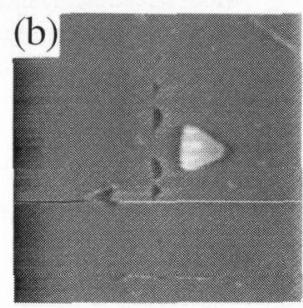

$100 \mathrm{~nm} \longmapsto$



Fig. 8 AFM images showing the process of the nanoscale groove formation on masking GaSe by AFM lithography. (a) Before the lithography; (b) After 1,000 scans with the cantilever; (c) After 2,000 scans; (d) After 3,000 scans.

が可能な基板温度に設定して $\mathrm{C}_{60}$ 分子を照射する。その 後試料を再び大気中に取り出し, 選択成長の様子を AFM を用いて調べている。

Fig. 8 は, GaSe 単層膜の加工の経過を観察した AFM 像である。この例ではカンチレバーを基板に対して 0.089 $\mathrm{nN}$ の斥力がかかるように押しつけ，上下方向に往復運 動している。なお Fig. 8（a）の加工前の像で, 中央下 にある暗い正三角形は $\mathrm{GaSe}$ が覆わずに残った $\mathrm{MoS}_{2}$ が 露出している領域, 右側の明るい正三角形は第 2 層目の GaSe アイランドである。このような場所は AFM 加工 した位置を $\mathrm{C}_{60}$ 照射後に再発見するための目印として利 
(a)
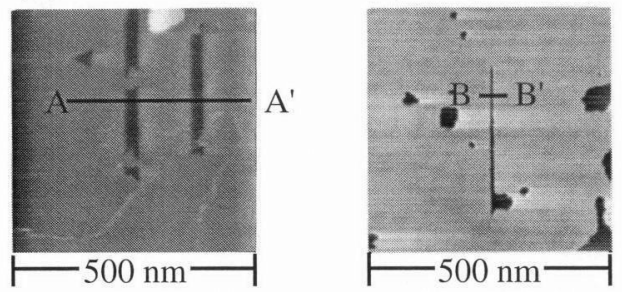

(b)
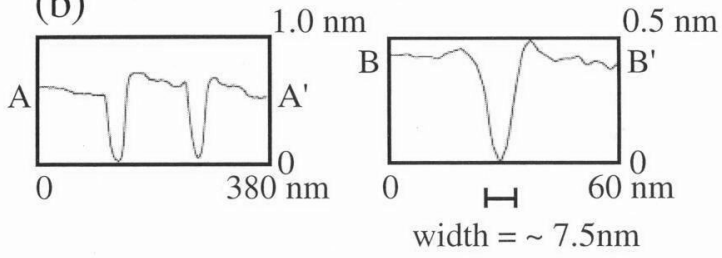

Fig. 9 (a) AFM images of grooves created by AFM lithography on $\mathrm{GaSe} / \mathrm{MoS}_{2}$ substrates; (b) Height profiles of the lines shown in (a).

用できる。

Fig. 8 (b)-(d) は，それぞれカンチレバーを 1,000 回, 2,000回, 3,000回往復した後の AFM 像である。まず $\mathrm{GaSe}$ 表面に小さな穴が多数形成され, それらが上下方 向に広がって接続し, 最終的に細長い溝が形成されるこ とがわかる。この例では幅約 $30 \mathrm{~nm}$ の溝が形成されて いる。Fig.9は, 加工した溝の断面プロファイルを AFM 像から求めたものである。右側のものはこれまでに加工 できた中で最小の幅を持つ溝で, およそ $7.5 \mathrm{~nm}$ 幅のも のが加工されている。どの例でも, 溝の深さは約 $0.5 \sim 0.7$ $\mathrm{nm}$ と測定されており, GaSe 単層膜の厚さにほぼ一致し ている。GaSe が $\mathrm{MoS}_{2}$ よりも柔らかく加工され易いた めに選択的に切削されたと考えられるが，それによって 加工深さを一定に保つことが可能になっている。この様 な溝を繰り返し加工して, より複雑な文字や回路を描画 することも可能である。

Fig. 10 は，この AFM による加工を施した基板上への $\mathrm{C}_{60}$ 分子の照射前後の $\mathrm{AFM}$ 像である。上が照射前で, 図中右下の部分に「K」の文字を切削し, $\mathrm{MoS}_{2}$ を露出 させている。なお幾つかある暗い正三角形の領域は, GaSe が最初から覆っていない部分である。下は, 基板 温度を $180^{\circ} \mathrm{C}$ に設定して, 分子線強度 $4 \times 10^{-6} \mathrm{~Pa}$ の $\mathrm{C}_{60}$ 分子を 2 分間照射した後の AFM 像である。照射後の「K」 の文字の場所には, 他の最初から GaSe が覆っていなか った $\mathrm{MoS}_{2}$ 領域と同様に, 幾分溢れているものの, $\mathrm{C}_{60}$ 分子が選択成長していることがわかる。おそらく基板温 度が予定より低かったか，あるいは $\mathrm{C}_{60}$ の照射量が多す ぎたために GaSe 上へ溢れ出たものと思われるが，それ
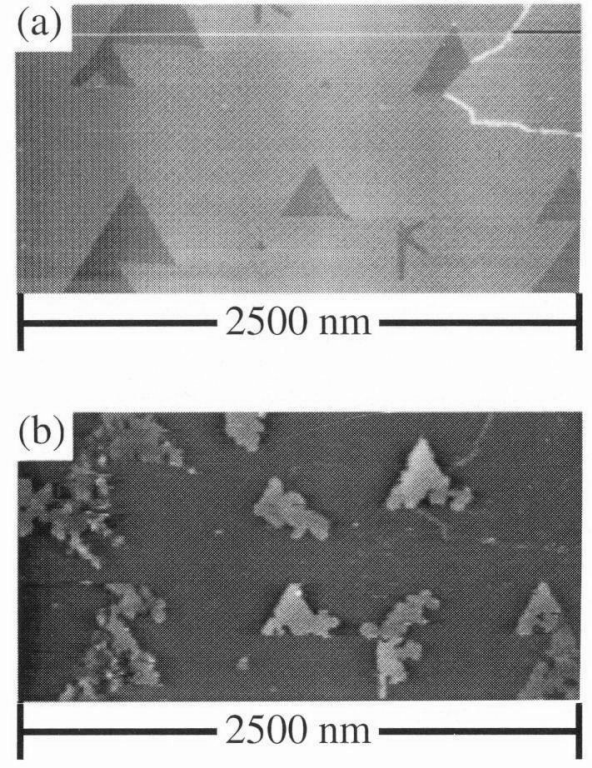

Fig. 10 AFM images before and after the growth of $\mathrm{C}_{60}$ on a nanosize " $\mathrm{K}$ " character created on a $\mathrm{GaSe} / \mathrm{MoS}_{2}$ substrate. (a) Before the growth of $\mathrm{C}_{60}$; (b) After the growth of $\mathrm{C}_{60}$.

以外の $\mathrm{MoS}_{2}$ が露出していなかった所には, $\mathrm{C}_{60}$ ドメイ ンが全く形成されていないことは確かである。成長条件 を最適に制御すれば, 加工した形状通りの $\mathrm{C}_{60}$ ナノ構造 が形成できるであろう。

\section{5. おりに}

以上述べてきた選択成長法は, 有機分子と基板表面と の相互作用の強さが，基板の種類と基板温度に依存する ことを利用している。しかし具体的に何が相互作用の強 弱をもたらしているのか, は未解明である。今回のどの 選択成長の系でも基板と成長物質間には共有結合のよう な強い相互作用はなく, 両者間で化学反応が起きていな いことは確かである。基板表面と有機分子の間に働くと 考えられる, 静電的相互作用やファンデアワールス相互 作用の様な比較的弱い作用の強弱が，何によってもたら されるのか, について探求することが, 今後の我々の課 題である。またこれまでは有機分子性結晶について選択 成長を試みてきたが, 付着確率の差が得られる成長物質 と基板物質の組み合わせを選べば，原理的には他の幅広 い物質への応用が可能である。さらに, 微細な選択成長 領域の形成手法として, AFM よりも高い分解能と加工 精度の得られる STM を用いれば, 原子スケールで制御 された選択成長も夢ではないと考えている。 
謝辞

本稿で述べた成果は, 鈴木 彰, 桜田剛史, 赤間信幸, 佐々木健太郎, 武田奈津子, 永堀 真の各学生の協力に より得られたものであり，ここに感謝します。また斉木 幸一朗助教授には貴重なご助言をいただきました。併せ て感謝します。

\section{文献}

1) Y. Arakawa and H. Sakaki: Appl Phys. Lett. 40, 939 (1982).

2) 難波 進編 : “メゾスコピック現象の基礎” (オーム 社, 1994).

3) E. Yablonovitch: Phys. Rev. Lett. 58, 2059 (1987).

4) F.L. Carter: "Molecular Electronic Devices" (Marcel Dekker, New York, 1982).

5) G.J. Ashwell: "Molecular Electronics" (Research Studies Press, Somerset, 1992).

6) H. Tada, K. Saiki and A. Koma: Jpn. J. Appl. Phys. 30, L 306 (1991).

7) M. Sakurai, H. Tada, K. Saiki and A. Koma: Jpn. J. Appl. Phys. 30, L 1892 (1991).

8) 多田博一, 小間 篤: 化学と工業 44, 2109 (1991).
9) 多田博一, 小間 篤: 表面科学 14, 452 (1993).

10) A. Suzuki, T. Shimada and A. Koma: Jpn. J. Appl. Phys. 235, L 254 (1996).

11) K. Ueno, K. Sasaki, N. Takeda, K. Saiki and A. Koma: Appl. Phys. Lett. 70, 1104 (1997).

12) K. Sasaki, K. Ueno and A. Koma: Jpn. J. Appl. Phys. 36, 4061 (1997).

13) K. Saiki, Y. Nakamura and A. Koma: Surf. Sci. 250, 27 (1991).

14) 斉木幸一朗 : 固体物理 28,627 (1993).

15) 黒田登志雄 : “結晶は生きている” (サイエンス社, 1984).

16) J. A. Wilson and A. D. Yoffe: Adv. Phys. 18, 193 (1969).

17) A. Kuhn, A. Chevy and R. Chevalier: Phys. Status Solidi (a) 31, 469 (1975).

18) A. Koma, K. Sunouchi and T. Miyajima: J. Vac. Sci. Technol. B 3, 724 (1985).

19) 小間 篤: 応用物理 62, 758 (1993).

20) K. Ueno, N. Takeda, K. Sasaki and A. Koma: Appl. Surf. Sci. 113/114, 38 (1997).

21) B. Parkinson: J. Am. Chem. Soc. 112, 7498 (1990).

22) Ed Delawski and B. Parkinson: J. Am. Chem. Soc. 114, 1661 (1992).

23) S. Hosoki, S. Hosaka and T. Hasegawa: Appl. Surf. Sci. 60/61, 643 (1992). 